\title{
Review Buku dan Penelusuran Kepustakaan: Memperkuat Keilmuan, Memperluas Wawasan
}

Ismail Suardi Wekke

Email: iswekke@gmail.com

Salah satu aktifitas yang diperlukan dalam perkuliahan pascasarjana adalah intensitas membaca. Dengan tidak melandasi proses di pascasarjana dengan itu, akan menjadi sebuah kondisi apa adanya yang tidak membantu sama sekali dalam pengayaan keilmuan.

\section{Bapak/Ibu, Saudara-Saudari}

Review Buku atau Book Review menjadi salah satu aktifitas perkuliahan setiap pekan. Ini untuk menjadi pengayaan bacaan dan juga referensi, sehingga dalam menghadapi dua tahun dalam program pascasarjana, mahasiswa akan mendapatkan beragam bahan bacaan.

Dari sini, setidaknya akan mebaca 8 buku jikalau dalam paruh pertama perkuliahan bersama saya. Membaca kemudian menuliskan kembali bacaan anda, dilanjutkan mengkonfirmasi bacaan anda dengan referensi lain, akan menjadi aktifitas yang memperluas cakrawala.

Bolehjadi, anda sudah membaca kepustakaan itu di masa lalu. Dengan membacanya kembali, ini juga akan membantu dalam proses penulisan tesis nantinya. Dengan mengendapkannya, anda kemudian dapat menggunakannya Kembali di satu kesempatan nanti.

Hanya saja, kondisi sistem kebut semalam begini tidak akan produktif. Untuk itu, saya membagi aktifitasnya menjadi latihan setiap pekan, di samping sebagai aktifitas yang rutin. Juga, akan menjadi kesempatan dalam menyelesaikan tugas ataupun kegiatan harian yang lain.

Selanjutnya, dengan bacaan buku-buku selama delapan pekan itu akan membantu anda dalam menulis latihan yang menjadi syarat ujian tengah semester. Dilanjutkan dengan aktifitas bersama dosen mitra yang menjadi team teaching selama delapan pekan. Setelah itu, kita akan memasuki ujian akhir semester.

Nah, di sini akan menjadi "tabungan" anda. Dimana dengan adanya delapan bahan bacaan yang menjadi pilihan anda itu akan dapat memperkaya artikel yang nantinya anda tulis untuk keperluan UTS dan UAS.

Saya ulangi kembali terkait dengan referensi. Perhatikan juga kriteria sebuah referensi (Wekke, 2021). Walaupun ini merupakan bagian yang terakhir dalam sebuah naskah, namun kita perlu memperhatikannya sejak awal (Wekke, 2019). Ketika ini diperhatikan juga pada bagian akhir, maka kita akan memulai kembali aktifitas dari awal.

Baik dalam menulis tesis ataupun juga menulis sebuah artikel perlu diperhatikan paling tidak empat hal, saya singkat dalam kata OSPEK (Wekke, 2020).

Olehnya, dengan mebaca sedikit demi sedikit, dan menuntaskannya juga sedikit demi sedikit akan menjadi bantuan dalam menjalani proses perkuliahan di pascasarjana. Sebuah gelar, sama pentingnya dengan penguasaan keilmuan. Sehingga, keduanya harus saling melengkapi. Akan sangat janggal, kalaulah hanya mencapai sebuah gelar tanpa diringi dengan penguasaan keilmuan sesuai dengan bidang yang ditekuni. 


\section{Daftar Pustaka}

Wekke, I. S. (2019). Memulai dari Akhir. Zenodo. https://doi.org/10.5281/zenodo.3551889.

Wekke, I. S. (2020). Penulisan Proposal Tesis: OSPeK. Zenodo. https://doi.org/10.5281/zenodo.3659989.

Wekke, I. S. (2021). Penelusuran Kepustakaan dengan Kriteria LaCAk. Zenodo. https://doi.org/10.5281/zenodo.5616156. 